\title{
Northern Ireland and the Euro: Changing Attitudes (2003-2013)
}

\section{Carine Berberi}

\section{Q OpenEdition \\ 12 Journals}

\section{Electronic version}

URL: http://journals.openedition.org/etudesirlandaises/3705

DOI: 10.4000/etudesirlandaises.3705

ISSN: 2259-8863

\section{Publisher}

Presses universitaires de Rennes

\section{Printed version}

Date of publication: 30 June 2014

Number of pages: 9-22

ISBN: 978-2-7535-3449-0

ISSN: 0183-973X

\section{Electronic reference}

Carine Berberi, « Northern Ireland and the Euro: Changing Attitudes (2003-2013) », Études irlandaises [Online], 39-1 | 2014, Online since 30 June 2016, connection on 20 April 2019. URL : http:// journals.openedition.org/etudesirlandaises/3705 ; DOI : 10.4000/etudesirlandaises.3705 


\title{
Northern Ireland and the Euro: Changing Attitudes (2003-2013)
}

\author{
Carine BERBERI \\ University of Tours, France
}

\begin{abstract}
Between 2003 and 2013 Northern Ireland has become more silent on the euro because of the eurozone crisis and the Eurosceptic discourse of the Cameron-Clegg government. Nevertheless, it has not become Eurosceptic and sends out mixed messages on this issue. While the viewpoint of the main parties and the population can mainly be explained by the republican/ unionist divide, business leaders - particularly those in border areas - remain the most enthusiastic owing to their trade links with Ireland.

Keywords: Ireland - Cross-border relations; European Union/EEC; Northern Ireland socio-economic policies; public debate; curreny; financial crisis

\section{Résumé}

De 2003 à 2013 l'attitude de l'Irlande du Nord à l'égard de l'euro a été de plus en plus prudente à cause de la crise de la zone euro et de la politique du gouvernement Cameron. Toutefois, elle n'est pas devenue eurosceptique, les opinions étant très partagées. Alors que le point de vue des partis et de la population dépend essentiellement du clivage entre unionistes et républicains, les entreprises demeurent plutôt favorables à l'euro en raison de leurs liens commerciaux avec l'Irlande.

Mots clés: Irlande - relations nord-sud; Union Européenne/CEE; Irlande sur Nord-politiques économiques et sociales; débat et sphère publics; monnaie; crise financière
\end{abstract}

Between 2003 and 2013 Britain has adopted an increasingly Eurosceptic attitude towards the euro and the eurozone crisis. In 2003 - under the Blair governments - the United Kingdom seemed almost ready to join the single currency. The official policy was that the government was in favour of joining the euro if the five tests ${ }^{1}$ set by Chancellor of the Exchequer Gordon Brown were passed and the British gave their approval in a referendum. These conditions were never met

1. There should be sustainable convergence between the business cycles and economic structures of the UK and the rest of the eurozone countries; there should be sufficient flexibility in the UK and in continental Europe to adapt to change and other unexpected events; joining EMU should create better conditions for businesses to make long-term decisions to invest in Britain; it should have a beneficial effect upon Britain's financial services industry and it should promote higher growth, stability, and a lasting increase in jobs. 
and the Blair governments never decided to join the euro. Yet, despite this cautious attitude, the Blair governments (between May 1997 and June 2007) as well as the Brown government (between June 2007 and May 2010) maintained a positive discourse, insisting on the need to meet the five economic tests and doing their best to help the eurozone countries to solve their economic problems. Since May 2010, the new Cameron-Clegg government has adopted quite a different policy, working less and less constructively with the European Union (EU) and clearly behaving as an "awkward partner" at European summits.

This change in policy has affected Northern Ireland over the past few years insofar as international relations/European issues remain reserved to Westminster ("excepted matters") and continue to be determined by the British government. Besides, Northern Ireland seems to be influenced by the increasingly Eurosceptic discourse of the coalition government, as exemplified by Sinn Féin which decided to support Britain joining the euro in 2003 but only grudgingly accepts the euro today.

This paper will consequently analyze the evolution of attitudes in Northern Ireland since 2003, focusing on the policies adopted by its main parties, i.e., Sinn Féin, the Social Democratic and Labour Party (SDLP), the Ulster Unionist Party (UUP) and the Democratic and Unionist Party (DUP), regarding the single currency and the euro crisis. We will also examine the viewpoint of the population as well as that of Northern Ireland to analyze the impact of the coalition government's policy upon society.

\section{The SDLP: the most consistent advocate of euro membership}

Until 2003 the SDLP was the only party - among the four above-mentioned political parties - to support Britain joining the euro and to call for the immediate introduction of the single currency in Northern Ireland. This viewpoint was justified by economic reasons: early entry into the euro would put an end to costly financial transactions, promote growth, maintain low inflation, provide lower interest rates, ensure a more stable financial system, attract investors and guard against currency speculation - which were all the more important to the SDLP, as nearly $60 \%$ of Northern Ireland's exports went to other EU member states $^{2}$. A single currency would also allow the unification of the whole of the island:

It is particularly important for us in Ireland that the whole of the island should be part of the single currency. Indeed if we look south of the

2. SDLP, "A Europe of the Future", European Election Manifesto, 1999. [http://www.sdlp.ie/]. 
border, we see proof that Euro membership really does pay. The average income in the Republic is now higher than in the $\mathrm{UK}^{3}$.

The EU has been vital in promoting closer relations between the two parts of the island and crucially between these islands. We have already abolished the economic border. We hope soon that we will also eliminate the monetary frontier by succeeding in bringing Northern Ireland into the single currency. The SDLP believes firmly that the UK should be part of the eurozone. The long-term benefits of euro membership are clear and substantial ${ }^{4}$.

Even though the SDLP later became a bit more silent on this issue - because of the cautious attitude of the Blair and Brown governments -, it has continued to support and to campaign for euro entry ${ }^{5}$. Thus, in 2009 - in the context of the economic and financial crisis - the SDLP used the same arguments in favour of the euro repeatedly, insisting on the stability the single currency would provide:

In Europe the SDLP will: [...] In the face of currency fluctuations, look for measures to promote currency stability and in the long term, campaign for the introduction of the Euro. Only an all-island approach to the economy, including the use of a single currency, will attract investors and enable Ireland North and South to seriously compete on the global stage ${ }^{6}$.

In spite of its criticism of the austerity approach of some European leaders the SDLP has called for policies aimed at stimulating economic growth since 2010, it has tried to reassure people, telling them over and over again that they should not be worried about the possibility of a eurozone break-up - following the eurozone crisis ${ }^{7}$ :

Some of us see the euro as a problem and some of us do not. Being in the euro has been an advantage to Ireland for many years. It has become a handicap at present because of the restrictions and constraints, but the eurozone works and has worked very well for many years. In the present crisis it has its handicaps and limitations. Some people are predicting that

3. SDLP, “SDLP's Rodgers challenges parties to support early membership of euro", 16 May 2001 [http://www. sdlp.iel].

4. SDLP, “SDLP leader warns Ireland against Euroscepticism”, 21 March 2002 [http://www.sdlp.ie/].

5. SDLP, "SDLP for Europe, Best Record, Best Agenda”, SDLP European Election Manifesto 2004, p. 5.SDLP,"A Better Way to a Better Ireland", SDLP Manifesto 2005, p. 14.

6. SDLP, "A Vision for Europe, Ambition for You”, European Election Manifesto 2009, p. 9.

7. SDLP, "Hanna: Wilson's comments about possible Eurozone break-up 'scary”, 11 November 2011. [http:// www.sdlp.ielindex.php/newsroom_medialnewsarticle/hanna_wilsons_comments_about_possible_eurozone_breakup_scary/]. 
the eurozone will collapse shortly; I do not accept that, and that is not the view of everybody ${ }^{8}$.

More generally, the SDLP has firmly criticized David Cameron's Eurosceptic policies. In December 2011, SDLP South Down MP Margaret Ritchie, who was the leader of the SDLP between February 2010 and November 2011, accused the government of marginalizing the UK within the EU following David Cameron's veto :

In walking away from the deal on the table at Brussels, David Cameron may be satisfying the Eurosceptic mob in his own party, but he is not necessarily getting the best deal for the UK, much less for the North of Ireland.

This move by the Prime Minister can only serve to harm our relationship with the EU and create a two-speed, two-tier Europe with those on the inside of the stabilisation deal sorting out the mess, and those on the outside, looking on ${ }^{10}$.

The SDLP has also condemned David Cameron's promise to organize an EU referendum ${ }^{11}$ if the Tories were reelected in 2015, as exemplified by SDLP leader Alasdair McDonnell who explained in January 2013 that such a referendum was not in the interests of Northern Ireland and would threaten "a significant sector of [its] economy ${ }^{12 "}$.

\section{Sinn Féin: to join or not to join?}

Like the SDLP, Sinn Féin is a nationalist party which favours a united Ireland (North and South). As already mentioned, it had opposed joining the euro until 2003. Not only had it opposed this project because of the loss of sovereignty it involved - by transferring control over domestic monetary policy to an unelected

8. Hansard, Parliamentary Debates, 15 December 2010, col. 963 (Alasdair McDonnell).

9. At the EU summit in Brussels in early December 2011 the British Prime Minister decided to use his veto to block treaty changes so as to protect Britain's financial services. Although the 26 other member states of the EU had agreed to enforce new austerity measures and tougher budget rules across Europe to solve their economic difficulties, David Cameron blocked these changes because his demands for greater protection of the City of London had been rejected.

10. UTV Live News, "Mixed NI reaction to Eurozone snub", 9 December 2011 [http://www.u.tv/News/Mixed-NIreaction-to-Eurozone-snublace5321c-2465-4f19-9f90-b591a58cb716].

11. On January 23, 2013 David Cameron promised he would hold an in/out referendum on membership of the European Union during the next parliament. Thus, British people would be able to decide whether Britain should remain in the EU by the end of 2017 if the Tories won the 2015 General Election.

12. SDLP, "McDonnell: EU referendum not in NI's interests", 23 January 2013 [http://www.sdlp.ie/index.php/ newsroom_medialnewsarticle/mcdonnell_eu_referendum_not_in_nis_interests/]. 
European Central Bank (ECB) - and the impact it would have on the economy of Northern Ireland, but it had also criticized the new obstacles which had been created between Northern Ireland and the Republic of Ireland:

The key policy objective of EMU is wholly dictated by tight deflationary fiscal criteria without any consideration of the impact of such policies on questions of unemployment, income and wage levels and social welfare protection. [...] Because the Six Counties has remained outside EMU and the 26 Counties inside it, another tier of obstacles have been placed in the way of creating a truly all Ireland economy. For Sinn Féin, which believes that such harmonization is essential for the development and regeneration of the economy as a whole, such a situation is more bad news ${ }^{13}$.

Yet, from 2002 onwards Sinn Féin became aware that it was increasingly difficult to be opposed to a project which was a reality in Ireland and could not be discarded easily ${ }^{14}$.

Consequently, in 2003 Sinn Féin made a U-turn on this issue and abandoned its policy of opposition to the single currency. This change was made official in the discussion document "Sinn Féin and the European Union" which was brought to the Annual Party Conference (Ard Fheis) in March 2003. In this document, Sinn Féin explained that the launch of the euro had increased economic differences between Northern Ireland and Ireland. Since asking the Republic of Ireland to withdraw from the eurozone was not a viable option in the medium term, Sinn Féin now called for the adoption of the euro in Northern Ireland. The main purpose of this change in attitude was to advocate a single currency for the whole island. This was made easier by the fact that Northern Ireland, in any case, was tied to the Bank of England, over which it had no control:

The adoption of a single currency throughout the island is a crucial part of the process of economic unification. [...] Sinn Féin has long opposed the undemocratic control of part of the Irish economy by British financial institutions. The adoption of the euro in the Six Counties would not involve a loss of democratic control, given that there is currently no control over the Bank of England. Indeed, entry of the Six Counties into the euro zone will strengthen our demands for greater Irish participation in the decision-making processes of the ECB. Sinn Féin will, therefore,

13. Sinn Féin, "Sinn Féin opposes Euro Monetary Union", An Phoblacht, 22 April 1999 [http://republican-news. org/archive/1999/April22/22emu.html].

14. Sinn Féin, "A critical engagement with Europe", An Phoblacht, 16 January 2003 [http://www.anphoblacht.com/ contents/9625]. 
support the adoption of the euro in the Six Counties in any future referendum on the issue ${ }^{15}$.

From then on the two nationalist parties of Northern Ireland, the SDLP and Sinn Féin, supported Britain joining the single currency. From 2007 onwards Sinn Féin confirmed the new policy it had adopted on the euro. More precisely, it tried to define an economic strategy aimed at unifying the whole Irish economy. One of the key elements of this strategy included: "Begin an open debate on the benefits of one currency for the whole island ${ }^{16}$." It was obvious here that Sinn Féin was making concessions in this field so as to get the support of the EU, as exemplified by the 2009 European Election Manifesto which clearly stated that Sinn Féin wanted to "step up the campaign for the EU to support Irish reunification ${ }^{17}$ ". The EU was henceforth considered as a means to put an end to partition and to reunify Ireland thanks to a series of measures which included the introduction of the euro in the North.

Like the SDLP, Sinn Féin has become a little more cautious on the single currency since 2010. Today Sinn Féin grudgingly accepts the euro because of the eurozone crisis and an increasing Euroscepticism in its ranks ${ }^{18}$. Thus, at the 2011 Ard Fheis in Belfast a motion called for a debate on the Republic of Ireland's continued membership of the euro. Cork Sinn Féin particularly criticized the austerity policies which were imposed on Ireland by the EU and strangled economic growth - the motion was not passed ${ }^{19}$. At the 2012 Ard Fheis Limerick City Sinn Féin repeated the same arguments insisting on the impact of the euro crisis on Britain's economy - the motion also failed:

This Ard Fheis believes that it is only through direct state management of the economy that we can bring to an early end our disgraceful levels of unemployment and debt and the first step to this end is control of our own currency. We therefore call on Sinn Féin to work with other like-minded individuals and groups towards an efficient and rapid dropping of the euro currency and the establishment of a state currency ${ }^{20}$.

In this unfavourable context, the call for the introduction of the euro in the North is no longer mentioned in official documents. Nevertheless, Sinn Féin has tried to adopt a precise policy on the European initiatives aimed at solving the

15. Sinn Féin, "Sinn Féin and the European Union - a discussion document brought to the party's Ard Fheis in March 2003", 9 March 2003 [www.sinnfein.org].

16. Sinn Féin, "Others Promise, We Deliver", 26 County General Election Manifesto 2007, p. 34.

17. Sinn Féin, European Election Manifesto 2009, p. 7.

18. See, for example: Sinn Féin, "Presidential Speech by Gerry Adams TD at Sinn Féin Ard Fheis, Waterfront Hall, Belfast", September 15, 2011 [http://www.sinnfein.ie/contents/21492].

19. Sinn Féin, "Economy Motions", Ard Fheis, 2011. [www.sinnfein.ielard-fheis-2011-motions].

20. Sinn Féin, "Economy Motions", Ard Fheis, 2012 [www.sinnfein.ielard-fheis-2012-motions]. 
eurozone crisis. This was exemplified by its stance in the run-up to the referendum on the EU Fiscal Treaty which was held in the Republic of Ireland on 31 May $2012^{21}$. Sinn Féin called for a series of measures - investment in jobs and growth, a write-down of toxic debt, and for the ECB to recapitalize the banks - so as to put an end to austerity policies which contracted eurozone economies:

The policies of austerity are strangling growth, not only in Ireland but across the Eurozone. EU unemployment is at an all-time high. The Troika programmes are not working because they are ignoring the real causes of the currency crisis. There is an urgent need for a change of direction away from austerity and towards policies focused on stimulating growth.

Any solution to the Eurozone crisis must follow a series of interrelated steps. [...] We need to invest in economic growth, primarily in the form of jobs. The European banking system must be cleansed of its toxic debts. There is also a need to reduce debt levels across the Eurozone through debt restructuring ${ }^{22}$.

Over the past few years, Sinn Féin's policy has also focused on the impact the decisions taken by European leaders could have on Ireland. Consequently, in December 2011 it did not condemn Cameron's veto and did not adopt the same attitude as other nationalist parties such as the Scottish National Party or Plaid $\mathrm{Cymru}^{23}$. In fact, Sinn Féin decided to criticize the Irish government which had opposed neither the austerity policies nor further integration which implied a transfer of more powers to Brussels:

The deal struck by 26 EU leaders on Friday, 9 December, in Brussels will not solve the eurozone crisis. In my opinion it will make matters worse. The agreement is not a fiscal compact. It is an austerity compact. It seeks to impose right-wing austerity policies in perpetuity. The difficulty for all of us is that the Taoiseach agrees with this. [...] the agreement last Friday also seeks to undermine member states' democracy ${ }^{24}$.

21. The EU Fiscal Treaty was approved by referendum on 31 May 2012, by $60.3 \%$ to $39.7 \%$, on a turnout of $50 \%$. It was designed to safeguard and stabilize the euro currency.

22. Sinn Féin, "Budget 2013 European Impact", March 2013 [http://www.sinnfein.ie/budget-2013-european-impact\#.UnT5rPlLNe4].Sinn Féin, "EU leaders must change tack to deal with mounting Euro crisis - Doherty", 23 July, 2012.

23. Following Cameron's decision to veto the EU Treaty on the eurozone debt crisis at the EU summit of December 2011, Alex Salmond (SNP) and Ieuan Wyn Jones (PC), for example, accused the British government of marginalizing the UK within the EU.

24. Sinn Féin, "Adams challenges Taoiseach on Euro Summit outcome", 14 December 2011 [http://www.sinnfein. ielcontents/22213]. 
One of the motions passed at the 2013 Ard Fheis also accused the Irish Government of failing to protect Irish interests - both political and economic - in the context of austerity ${ }^{25}$.

\section{The two main unionist parties: a consistent opposition to the Euro}

Contrary to the two most popular nationalist parties which have supported Britain joining the euro since 2003, the two main unionist parties - the DUP and the UUP - are opposed to the single currency and support the retention of the pound Sterling.

The DUP and the UUP are against the euro for the same reasons as those mentioned by Sinn Féin before 2003, i. e., economic and political reasons linked to the loss of sovereignty involved by such a scheme. More precisely, they consider that the single currency would mean the loss of economic control to an undemocratic ECB, as mentioned by Jim Allister, a member of the DUP and MEP for Northern Ireland between 2004 and 2007, or by Jim Nicholson, a UUP politician and MEP for Northern Ireland since 1989:

Giving up our own currency would impact adversely on Northern Ireland and our economy. Key economic decisions would be handed over to faceless, unelected and unaccountable bankers and bureaucrats in Europe. The DUP is committed to accountable government. Accountable elected UK politicians are better placed to take economic decisions on our behalf ${ }^{26}$.

Jim Nicholson believes it is in the UK's national interest to retain Sterling and control over interest rates, exchange rates and tax policy. To surrender them would threaten our basic concept of democracy - that we are governed and taxed by those we elect and can dismiss ${ }^{27}$.

In their 2010 election manifesto the DUP kept repeating the same ideas:

The DUP opposes the UK entering the Euro zone. Giving up our national currency would mean surrendering a vital tool for running the British economy and an unacceptable loss of independence ${ }^{28}$.

25. Sinn Féin, "European Union and International Affairs - Motions", Ard Fheis, 2013. [www.sinnfein.ielard-fheis2013-motions].

26. DUP, "Leading for Ulster - European Election 2004”, Manifesto Magazine, p. 19.

27. UUP, Ulster Unionists Manifesto, 2004, p. 2.

28. DUP, “Let's Keep Northern Ireland Moving Forward”, Manifesto 2010, p. 65. 
In fact, the DUP and the UUP have always supported cooperation between European states and opposed the creation of a "European Super-State" which would include monetary union, economic integration, political union, a harmonized tax-policy... Their main purpose is to retain national control of their economy.

The two unionist parties also fear the impact joining the euro could have on Britain's and Northern Ireland's economy - particularly on wages and employment $^{29}$. In 2003/2004 they mostly criticized the convergence criteria defined by the Maastricht Treaty - the latter were considered as deflationary fiscal criteria because they focused on the fight against inflation. This argument was rather justified since high unemployment and low economic growth were noticeable in many countries of the eurozone at the beginning of the $21^{\text {st }}$ century. The DUP and the UUP were all the more worried as they were quite aware that the ECB would never protect Northern Ireland's interests: "Some countries in the Euro zone are already experiencing problems as the ECB puts the priorities of the likes of Germany and France above theirs ${ }^{30}$."

Today the DUP and the UUP mostly bring to the fore the economic difficulties faced by some members of the eurozone, like Greece, the Republic of Ireland, Spain, Portugal and Italy - owing to the euro crisis $^{31}$. The UUP, above all, has strongly condemned the inability of eurozone countries to take the right measures to solve the crisis, calling into question the validity of the eurozone:

I [Jim Nicholson] have always voiced my concern that the entire Eurozone was conceived too fast, too soon. Greece, along with others, was admitted into an ill-conceived idea at a time when their economies were not strong enough. As a result, they are now paying the price during this economic crisis where they face further budget cuts [...].

The inability of Greece and other Eurozone nations to put concrete plans in action and push forward previously agreed actions is causing the UK, and the Northern Ireland economy, considerable harm. [...] I appeal to the Eurozone leaders to put a stop to the continuing uncertainty and sort out the problems that their premature 'one currency, one continent' vision has created ${ }^{32}$.

29. UUP, Ulster Unionists Manifesto, 2004, p. 2.

30. DUP, "Allowing Business to Prosper", The Democratic Unionist Party's Policy on Business and Economic Development, 2003, p. 22.

31. UUP, "Ulster Unionist Leader Elliott challenges DUP propaganda", 21 January 2011 [http://www.uup.org].

32. UUP, "Nicholson urges Eurozone to take further action", 15 February 2012 [http://uup.org/news/554/Nicholson-urges-Eurozone-to-take-further-action\#.UnT9GPILNe4]. 
The two unionist parties have also welcomed David Cameron's promise to organize a referendum on Britain's EU membership ${ }^{33}$. In their 2010 general election manifesto the DUP had already called for a referendum on major constitutional issues, such as the Lisbon Treaty, considering that "too many powers have been ceded by our national Government to the European Union ${ }^{34 "}$.

In fact, the UUP seems to be rather less Eurosceptic than the DUP. Thus, it has consistently promoted a more competitive and flexible EU as well as an objective debate on Britain and Europe:

I [Jim Nicholson] believe a focused and comprehensive debate concerning the on-going relationship between the UK and the EU is essential. This must be an informed debate based on the facts. A debate that clearly outlines the impact of all aspects of EU membership both positive and negative including our financial contributions and gains, the impact of the single market on jobs and trade, European funding and the costs and benefits derived from European legislation ${ }^{35}$.

On the contrary, in its 2010 manifesto, the DUP criticized "the continual power-grab exercised by the European Commission" - which should be more strongly opposed by the British government - and wanted Britain to look beyond Europe for greater cooperation: "Northern Ireland already has many industrial and trading links with India, and it will be vital for maximizing the UK's influence in the world to deepen relations with China and India ${ }^{36}$."

\section{Society: mixed views}

As far as the population of Northern Ireland is concerned, it sends out mixed messages. In fact, the euro has created tensions within the country, particularly in the early 2000s. Indeed, a survey carried out in June 2003 showed that the public remained hostile to the euro but the gap between the Yes and No votes was rather narrow: $48 \%$ opposed joining the single currency, 39\% supported it and 14\% said they did not know. Nevertheless, it was clear that the level of public opposition to the euro was much higher in Britain, reaching about 57\%, if we compared the above-mentioned figures with the outcome of polls carried out in the UK as a whole in $2003^{37}$.

33. UUP, "Nicholson comments on David Cameron's speech on the EU", 23 January 2013 [http://uup.org/ news/1481/Nicholson-comments-on-David-Cameron-s-speech-on-the-EU\#.UnT9Q_lLNe4].

34. DUP, “Let's Keep Northern Ireland Moving Forward”, Manifesto 2010, p. 65.

35. UUP, "Nicholson comments on David Cameron's speech on the EU", 23 January 2013 [http://uup.org/ news/1481/Nicholson-comments-on-David-Cameron-s-speech-on-the-EU\#.UnT9Q_lLNe4].

36. DUP, "Let's Keep Northern Ireland Moving Forward”, Manifesto 2010, p. 65.

37. IPSOS MORI, "Joining the Euro - Trends since 1991", 8 March 2007 [http://www.ipsos-mori.com/researchpub- 
Since 2003 few polls have been carried out to analyze the opinion of the people of Northern Ireland on the single currency - which is logical considering the policies which have been implemented by the British governments and the eurozone crisis. It is consequently very difficult to precisely assess what proportion of the population would still be favourable to joining this scheme. However, the gap between the Yes and No votes in Northern Ireland seems to reflect the viewpoints of the two communities. The 2011 Census showed that $42 \%$ of the population of Northern Ireland were protestant (46\% in 2001) whereas $41 \%$ were catholic $(40 \% \text { in } 2001)^{38}$. Generally speaking, the Republicans, most of whom are Catholic, support euro membership because such a step would allow Northern Ireland and the Republic of Ireland to share a common currency. On the contrary, Unionists, most of whom are Protestant, fear that euro membership could be a step towards the reunification of Ireland (North and South) ${ }^{39}$.

As far as business leaders in Northern Ireland are concerned, most of them support joining the euro. According to a poll conducted by business advisors, PricewaterhouseCoopers $(\mathrm{PwC})$, in May 2003, almost two-thirds (63\%) of Northern Ireland companies favoured euro membership (24\% against ${ }^{40}, 13 \%$ remaining undecided) because it could be beneficial for their business, removing currency transaction costs, ensuring greater price transparency and creating increased competitiveness. The support was particularly strong in the west and north west of the Province, i. e., near the border, owing to the trade links with the Republic of Ireland ${ }^{41}$. Indeed, to a large extent, the enthusiasm of businesses in Northern Ireland can be explained by their export activity, as exemplified by $\mathrm{PwC}$ chief economist Philip McDonagh in 2003:

Slow economic recovery and low-cost competition is hurting local exporters. Despite the strengthening Euro, exporters to Ireland and other parts of the Eurozone perceive currency volatility as yet another barrier to trade. In border areas and amongst retailers, where dual currency has become a way of life, the euro is already accepted. As customers in the

lications/researcharchive/poll.aspx?oItemId $=78$ o view $=$ wide $]$.

38. NISRA, "Census 2011: Detailed Characteristics for Northern Ireland on Health, Religion and National Identity”, Statistics Bulletin, 16 May 2013, p. 27.

39. Maurice Neill, "Ulster opposes entry to the euro", Belfast Telegraph, 27 June 2003 [http://www.belfasttelegraph. co.uk/imported/ulster-opposes-entry-to-the-euro-28151337.htmll.

40. The businesses who opposed any move to join the single currency at the time said they feared higher taxes, a loss of control over the economy, with interest rates being set by the ECB. They also claimed that the UK did more business with countries outside the eurozone.

41. "Northern Ireland businesses favour the euro", Northern Ireland on the Internet, 19 May 2003 [http://www.4ni. co.uk/northern_ireland_news.asp?id=16540. 
Republic and the EU align their supply chains to the euro, local suppliers and exporters are feeling isolated. This is not a surprising result ${ }^{42}$.

This attitude was confirmed in 2006 in a survey carried out by Grant Thornton, a global network of independent assurance, tax and advisory firms. This new research which focused on British medium-sized companies revealed that within the UK, support for euro entry was the strongest in Northern Ireland, reaching $58 \%$, compared with $35 \%$ in the UK. It seems that the trade links with the Republic of Ireland explained the enthusiastic viewpoint of businesses in Northern Ireland ${ }^{43}$. Nevertheless, this assertion should be somewhat qualified today insofar as Northern Ireland has been increasingly exporting to countries outside the eurozone since 2007. The figures published by the Department of Finance and Personnel of Northern Ireland (DFPNI) in March 2013 even showed that Northern Ireland exported more services to these countries than it did with eurozone members and the Republic of Ireland ${ }^{44}$.

Since 2010 businesses in Northern Ireland have been concerned about the impact of the eurozone crisis on their export market. In January 2012 Francis Martin, Managing Partner at business advisory firm BDO, made it quite clear:

For Northern Ireland, the pathway out of economic uncertainty is expanding our export market so it becomes increasingly diverse, sustainable and able to generate significant levels of employment. We have much in our favour - highly educated and skilled staff, relatively low labour costs, proximity to both the US and Europe. But the crisis mode of euro governance does little or nothing to engender business confidence ${ }^{45}$.

They have also criticized David Cameron's promise to hold a referendum on Britain's membership of the EU, considering it would not be in Northern Ireland's interests and would create much uncertainty. Philip Gilliland, President of the Londonderry Chamber of Commerce, brought to the fore the trading links between Ulster, the Republic of Ireland and the EU in January 2013:

European Union membership is especially important for Northern Ireland, given our land border and close trading connections with the Republic. This is even more true for Derry as a border city.

42. "Northern Ireland businesses favour the euro", Northern Ireland on the Internet, 19 May 2003 [http://www.4ni. co.uk/northern_ireland_news. asp?id=16540.

43. "Support for euro entry among mid-sized UK companies at all-time low - survey", AFX News, 27 June 2006 [http://www.lse.co.uk/FinanceNews.asp?ArticleCode=5srwm0lt75iqa1 t\& ArticleHeadline=Support_for_euro_entry_among_midsized_UK_companies_at_all_time_low_survey].

44. DFPNI, "Exporting Northern Ireland Services Study 2011", Statistics Bulletin, 29 May 2013, p. 6, p. 14.

45. Gavin Walker, "Northern Ireland business recovery could be as simple as 1, 2, 3", Businessfirstonline, 9 January 2012 [http://www.businessfirstonline.co.uk/our-guest-bloggers/northern-ireland-business-recovery-could-be-assimple-as-1-2-3/]. 
If the Prime Minister's negotiations with EU colleagues go badly, there is presumably a risk that the UK would leave the EU. While that would be damaging to international trade conducted by British companies, it would be potentially disastrous for businesses in Northern Ireland. If Northern Ireland were no longer part of the same trading group as the Republic, the repercussions could be severe ${ }^{46}$.

Even though the business leaders of Northern Ireland are more enthusiastic about joining the euro, their viewpoint broadly reflects that of most British business leaders. The latter have tended to remain silent on the euro issue and on Europe more generally since 2010 but they remain pro-euro and pro-Europe because the EU is Britain's biggest trading partner ${ }^{47}$. Most business leaders in the UK would consequently like Britain to remain a part of the EU, considering that exiting it would hurt investment and damage British trade ${ }^{48}$.

\section{Conclusion}

Between 2003 and 2013 attitudes in Northern Ireland towards the euro have somewhat changed, but not as much as those in Britain as a whole - even if the Province has become more silent on this issue because of the eurozone crisis and the policy of the coalition government. In fact, the mixed messages Northern Ireland sends out on the single currency reflect the divisions in its society.

The main republican parties, the SDLP and Sinn Féin, have both supported Britain joining the euro since 2003, a step which would, above all, allow them to unify the island (North and South). Even though they have tended to be more cautious since 2010, they have tried to find solutions to the euro crisis, encouraging eurozone countries to put an end to their austerity approach and to adopt policies aimed at stimulating growth. One should note that unlike the SDLP which has always favoured the single currency, Sinn Féin seems to hesitate over the stance it should adopt on this issue today. It seems obvious though that it will stick to the same policy as long as the Republic of Ireland is part of the eurozone.

The two main unionist parties, the DUP and UUP, have been rather consistent in their opposition to the euro owing to the loss of sovereignty it would involve and the impact it could have on Northern Ireland's economy. Contrary

46. Philip Gilliland, "EU Referendum”, The Londonderry Chamber of Commerce, 23 January 2013 [http://www. londonderrychamber.co.uk/news/eu-referendum---philip-gilliland.html].

47. Karen Kiernan, "Business leaders say Britain should still join euro", BBC, 14 July 2010 [http://www.bbc.co.uk/ news/business-10642064].Stephen Castle, "British Business Leaders Stay Silent on E. U. Exit", New York Times, 3 December 2012 [http://www.nytimes.com/2012/12/04/business/global/uk-backers-of-europe-want-business-tospeak-up].

48. Charles Forelle, "U.K. Businesses Say Yes to EU, No to Its Rules”, Wall Street Journal, 23 January 2013 [http:// online.wsj.com/news/articles/SB10001424127887323539804578259882086765390]. 
to the two main republican parties, they have thus welcomed David Cameron's decision to organize an EU referendum and seem to support the repatriation of powers from Brussels to the UK.

This republican/unionist divide enables us to explain the viewpoint of the population of Northern Ireland on the single currency. Indeed, opinions are mixed because generally speaking, Unionists, most of whom are Protestant, are opposed to the euro which, they believe, would lead to the reunification of Ireland (North and South) whereas Republicans, most of whom are Catholic, support this scheme which would allow them to establish a single currency for the whole island. Nevertheless, it is quite difficult to establish the proportion of people who still support the UK joining the euro today because few polls have been carried out recently on this issue.

Similarly polls have also been conducted among business leaders over the past few years. Yet, it appears that Northern Ireland businesses, particularly those in border areas, are the most enthusiastic in the UK because of their trade links with the Republic of Ireland. These trade links explain why companies in Northern Ireland are still in favour of the euro today and are concerned about the impact of the eurozone crisis on their export market - even if they increasingly export to countries outside the eurozone. As long as the Republic of Ireland is part of the euro area, this viewpoint will certainly not change.

The evolution of Northern Ireland's attitude towards the euro in the medium term will consequently depend on the future of the eurozone and the continued membership of the Republic of Ireland in the EU. Yet, the results of the EU referendum which will be organized by David Cameron in 2017 will also influence Northern Ireland. If Britain decides to leave the EU, Northern Ireland will have to make a decision about its future within the EU and tensions will certainly arise as a result of the republican/unionist divide on this issue. 